\title{
SOCIAL ENTREPRENEUR SHIP: INOVASI DAN TANTANGANNYA DI ERA PERSAINGAN BEBAS
}

\author{
Agung Surya Dwianto \\ STIE Pertiwi \\ Email:ag_dwi_ant@yahoo.co.id
}

\section{ARTIICLE INFO}

Social Entrepreneurship,

Social Innovation,

Challenges Faced

\section{ABSTRACT}

In many countries, especially in developing countries, there are many social problems that need to be resolved. The high level of poverty and unemployment, the lack of available health facilities, or the low quality of existing education, is an acute problem that becomes a tough domestic work for a developing country's government. Given the current global conditions, where free competition is inevitable, it certainly adds to the long list of strategies that the government must take to tackle various social problems. The government can not struggle and work alone in dealing with the complexity of the existing problems, it is certainly necessary for the active role of all elements of the society so that the problems that whack, can unravel and be solved. One step that can be taken by the government in order to empower and protect the people in the era of free competition is to support, develop, and multiply the existence of social entrepreneurship. Social entrepreneurship has the potential to provide some social solutions that affect a country.

This paper shows the concept of social entrepreneurship as historical background, characteristics, challenges faced and business model of social entrepreneurship in order to overcome various social problems that can have a positive impact on economic development.

\section{Persaingan Bebas dan Dampaknya}

Suka tidak suka, persaingan bebas telah menjadi suatu keniscayaan yang sedang terjadi dan mesti dihadapi oleh suatu bangsa. Persaingan bebas (baca globalisasi) memiliki dua sisi yang tidak dapat dipisahkan. Satu sisi, persaingan bebas memberikan begitu banyak peluang dan juga kesempatan, baik itu bagi individu maupun bagi suatu kelompok (negara) untuk dapat berkembang. Sementara disisi yang lain, tatkala individu ataupun kelompok (negara), tidak mempersiapkan dirinya secara baik, maka bukannya peluang ataupun keuntungan yang akan menghampiri, namun yang terjadi justru sebaliknya.

Indonesia dengan kesembilan negara anggota ASEAN lainnya telah menandatangani deklarasi blueprint Masyarakat Ekonomi ASEAN (MEA) untuk memulai suatu langkah integrasi dari segi ekonomi (Firdaus Djaelani, 2016). Hal ini membuat Indonesia harus berusaha memperbaiki seluruh kualitas diberbagai aspek agar mampu bertahan ditengah era persaingan bebas yang semakin hari semakin kompetitif. Pemerintah Indonesia harus fokus dan peduli pada berbagai masalah yang menderanya, seperti kemiskinan dan pengangguran yang relatif tinggi, minimnya fasilitas kesehatan yang tersedia, atau rendahnya kualitas pendidikan yang ada.

Khususnya pengangguran, masalah ini adalah problema yang besar bagi suatu negara, baik itu negara yang tergolong maju, maupun negara yang masih dalam taraf negara berkembang. Perlu pengkajian yang mendalam dan serius, serta harus melibatkan seluruh pihak yang terkait dan juga berkompeten untuk mengatasi masalah pengangguran hal ini.

Terbaru, Badan Pusat Statistik (BPS) melansir data mengenai kondisi tenaga kerja di Indonesia. Tingkat Pengangguran Terbuka (TPT) Februari 2015 sebesar 5,81 persen meningkat dibandingkan TPT Februari 2014 (5,70 persen). Dari data tersebut, pada Februari 2015, penduduk bekerja masih didominasi oleh mereka yang berpendidikan SD ke bawah sebesar 45,19 persen, sementara penduduk bekerja dengan pendidikan Sarjana ke atas hanya sebesar 8,29 persen.

Tingginya angka pengangguran di Indonesia dipengaruhi juga oleh kualitas ketenagakerjaan di Indonesia yang masih memprihatinkan baik dilihat dari sisi kualifikasi maupun kompetensi (Bunyamin 
Maftuh, 2016). Pembangunan Sumber Daya Manusia belum menunjukkan hasil yang menggembirakan. Indeks pembangunan sumber daya manusia (Human Development Index) yang dikeluarkan oleh United Nations Development Programme Indonesia menempati urutan ke- 113 dari 188 negara. Menurut catatan mereka, Indonesia masuk ke dalam kategori medium human development.

Angka pengangguran yang cukup besar tersebut tentunya dapat menimbulkan masalah sosial yaitu kemiskinan. Diperlukan beberapa solusi nyata untuk menekan permasalahan sosial yang timbul karena tingginya tingkat pengangguran akibat terbatasnya lahan pekerjaan. Kondisi yang dihadapi akan semakin diperburuk dengan situasi persaingan bebas (misal pemberlakuan Masyarakat Ekonomi ASEAN/MEA) yang akan menghadapkan lulusan perguruan tinggi Indonesia bersaing secara bebas dengan lulusan dari perguruan tinggi asing. Oleh karena itu, lulusan perguruan tinggi perlu diarahkan dan didukung untuk tidak hanya berorientasi sebagai pencari kerja (job seeker) namun juga dapat dan siap menjadi pencipta pekerjaan (job creator) (Suharti dan Sirine, 2009).

Salah satu cara untuk mengatasi permasalahan sosial yang dewasa ini menjadi perhatian besar negara-negara berkembang termasuk Indonesia adalah mengembangkan kewirausahaan sosial atau popular dengan nama social entrepreneurship.

\section{Konsep Social entrepreneurship}

Definisi social entrepreneurship banyak dikembangkan di sejumlah bidang yang berbeda, mulai dari non-profit, profit, sektor publik, dan kombinasi dari ketiganya. Menurut Bill Drayton (pendiri Ashoka Foundation) selaku penggagas social entrepreneurship terdapat dua hal kunci dalam social entrepreneurship. Pertama, adanya inovasi sosial yang mampu mengubah sistem yang ada di masyarakat. Kedua, hadirnya individu yang mempunyai visi, kreatif, berjiwa wirausaha (entrepreneurial), dan beretika di belakang gagasan inovatif tersebut. Hulgard (2010) merangkum definisi social entrepreneurship secara lebih komprehensif yaitu sebagai penciptaan nilai sosial yang dibentuk dengan cara bekerja sama dengan orang lain atau organisasi masayarakat yang terlibat dalam suatu inovasi sosial yang biasanya menyiratkan suatu kegiatan ekonomi

Social entrepreneurship merupakan sebuah istilah turunan dari entrepreneurship. Gabungan dari dua kata, social yang artinya kemasyarakatan, dan entrepreneurship yang artinya kewirausahaan. Pengertian sederhana dari social entrepreneur adalah seseorang yang mengerti permasalahan sosial dan menggunakan kemampuan entrepreneurship untuk melakukan perubahan sosial (social change), terutama meliputi bidang kesejahteraan (welfare), pendidikan dan kesehatan (healthcare) (Cukier, 2011).

Hal ini sejalan dengan yang diungkap oleh Schumpeter dalam Sledzik (2013) yang mengungkap entrepreneur adalah orang yang berani mendobrak sistem yang ada dengan menggagas sistem baru. Jelas bahwa social entrepreneur pun memiliki kemampuan untuk berani melawan tantangan atau dalam definisi lain adalah seseorang yang berani loncat dari zona kemapanan yang ada. Berbeda dengan kewirausahaan bisnis, output yang ingin diraih oleh social entrepreneurship tidaklah profit belaka, tetapi juga bertujuan memberikan efek positif bagi masyarakat.

Social entrepreneur adalah agen perubahan (change agent) yang mampu untuk melaksanakan citacita, mengubah, dan meningkatkan nilai-nilai sosial dan menjadi penemu berbagai peluang untuk melakukan perbaikan diberbagai bidang (Santosa, 2007). Seorang social entrepreneur selalu melibatkan diri dalam proses inovasi, adaptasi, pembelajaran yang terus menerus bertindak tanpa menghiraukan berbagai hambatan atau keterbatasan yang dihadapinya dan memiliki akuntabilitas dalam mempertanggungjawabkan hasil yang diperolehanya, kepada masyarakat.

Pemahaman di atas memberikan suatu pengertian bahwa social entrepreneurship terdiri dari empat elemen utama yakni social value, civil society, innovation, and economic activity (Palesangi, 2013).

$>$ Social Value. Ini merupakan elemen paling khas dari social entrepreneurship yakni menciptakan manfaat sosial yang nyata bagi masyarakat dan lingkungan sekitar.

$>$ Civil Society. Social entrepreneurship pada umumnya berasal dari inisiatif dan partisipasi masyarakat sipil dengan mengoptimalkan modal sosial yang ada di masyarakat.

$>$ Innovation. Social entrepreneurship memecahkan masalah sosial dengan cara-cara inovatif antara lain dengan memadukan kearifan lokal dan inovasi sosial.

$>$ Economic Activity. Social entrepreneurship yang berhasil pada umumnya dengan menyeimbangkan antara antara aktivitas sosial dan aktivitas bisnis. Aktivitas bisnis/ekonomi dikembangkan untuk menjamin kemandirian dan keberlanjutan misi sosial organisasi. 
Gairah terhadap social entrepreneurship dewasa ini meningkat karena terjadinya pergeseran social entrepreneurship yang semula dianggap merupakan kegiatan yang tidak menguntungkan" (antara lain melalui kegiatan amal) menjadi suatu kegiatan yang berorientasi bisnis (entrepreneurial private-sector business activities) (Utomo, 2014).

\section{Inovasi yng dilakukan social entrepreneur}

Inovasi terjadi karena perasaan tidak puas terhadap kondisi dan situasi yang ada serta adanya peluang untuk memperbaiki keadaan yang ada, inovasi harus dijadikan sebagai suatu alat dan bukan suatu tujuan, tujuan dari suatu inovasi adalah perubahan atau perbaikan dari kondisi yang ada menjadi lebih baik, namun tidak semua perubahan dapat dikatakan sebagai suatu inovasi (Saiman, 2011).

Sementara Moulaert (2013) berpendapat bahwa inovasi sosial bisa dimulai dari berbagai sektor dalam bidang perekonomian, tidak hanya di sektor non-profit, tetapi juga di sektor publik dan swasta. Di sisi lain, inovasi sosial tidak terbatas pada masalah kesejahteraan tetapi juga mungkin terkait dengan isu-isu perlindungan lingkungan dan pembangunan berkelanjutan (dalam kaitannya dengan korporasi, salah satu "bentuk" sosial entrepreneurship yang ada dalam suatu organisasi adalah dengan dilaksanakannya program corporate social responsibility).

Inovasi sosial sangat berkaitan dengan social entrepreneurship. Inovasi sosial adalah pondasi bagi seorang social entrepreneur dalam menjalankan bisnis atau kegiatannya untuk mencari kesempatan, memperbaiki sistem, menemukan pendekatan yang baru serta menciptakan solusi terhadap perubahan lingkungan yang lebih baik (Widiastusy, 2011). Seorang social entrepreneur mencari cara yang inovatif untuk memastikan bahwa usahanya akan memiliki akses terhadap sumber daya yang dibutuhkan selama mereka dapat menciptakan nilai sosial (Mort \& Weerawardena, 2003).

\section{Model Bisnis Social entrepreneurship}

Sementara itu, Osterwalder \& Pigneur (2010) mendefinisikan model bisnis sebagai gambaran dasar pemikiran tentang bagaimana organisasi menciptakan dan memberikan nilai. Model bisnis memperlihatkan cara berpikir tentang bagaimana sebuah perusahaan menghasilkan uang. Model bisnis dan bentuk organisasi sangat berpengaruh terhadap kemampuan perusahaan untuk tumbuh dan berkembang secara berkelanjutan. Seperti halnya bisnis pada umumnya, kesempatan yang dimiliki oleh sosial entrepreneurship harus didukung oleh model bisnis yang masuk akal dan realistis.

Social entrepreneurship harus dibangun dengan landasan sebuah jaringan dan koneksi yang kuat serta terpadu dengan pengetahuan mengenai bisnis, di mana mereka dapat menemukan nilai secara individual dan bersama-sama secara keseluruhan sebagai sebuah ekosistem. Social entrepreneurship dianggap telah memiliki "sarang" (hive) apabila organisasi tersebut dapat mengandalkan kerjasama di lingkungan mereka berada dan bekerjasama secara intensif dengan para stakeholder.

Informasi yang didapatkan dari para pelanggan terkait perubahan yang terjadi di pasar dapat diartikan sebagai sebuah dynamic signal bagi social entrepreneurship, dimana para pelaku atau komunitas social entrepreneurship harus mengambil dan memproses informasi ini secara efisien sehingga dapat mengarah kepada nilai sosial yang ingin diciptakan. Proses ini yang digambarkan sebagai sebuah metafilter.

\section{Fenomena Kemunculan Grameen Bank Terhadap Perkembangan Social entrepreneurship di Indonesia}

Social entrepreneurship menjadi fenomena sangat menarik saat ini karena perbedaan-perbedaannya dengan wirausaha tradisional yang hanya fokus terhadap keuntungan materi dan kepuasan pelanggan, serta signifikansinya terhadap kehidupan masyarakat. Konsep social entrepreneurship mencapai puncak pemahamannya pada dekade tahun 2006 dengan dibuktikan di mata dunia internasional seorang Mohammad Yunus pemenang Nobel Perdamaian dalam kiprahnya bidang ekonomi mikro yang khusus ditujukan oleh kaum wanita di Banglades. Itu adalah pengakuan dan penghargaan untuk seorang Social entrepreneur (Social entrepreneurship).

Semenjak itu, termasuk Indonesia, mulai hangat memperbincangkan konsep Social entrepreneurship. Hal ini wajar mengingat bahwa fenomena keberhasilan Moh. Yunus dengan konsep Grammen Bank atas upaya memecahkan masalah sosial di negaranya, sesungguhnya tidak jauh berbeda dengan situasi masalah sosial yang terjadi di Indonesia. Konsep social entrepreneurship seolah menjadi sebuah alternatif pemikiran yang dapat memecahkan masalah sosial yang sedemikian kompleksnya terjadi di Indonesia. 
Dewasa ini terjadi pergeseran social entrepreneurship yang semula dianggap merupakan kegiatan "non-profit" (antara lain melalui kegiatan amal) menjadi kegiatan yang berorientasi bisnis (entrepreneurial private-sector business activities). Keberhasilan legendaris dari Grameen Bank dan Grameen Phone di Bangladesh menggambarkan salah satu contoh terjadinya pergeseran orientasi dalam menjalankan program social entrepereneurship. Hal ini menjadi daya tarik bagi dunia bisnis untuk turut serta dalam kegiatan social entrepreneurship, karena ternyata dapat menghasilkan keuntungan finansial. Begitu peliknya permasalahan sosial yang terjadi di Indonesia pun telah mendorong tumbuhnya berbagai komunitas social entrepreneurship, dua di antaranya adalah Asosiasi Social entrepreneurship Indonesia (AKSI) dan Indonesia setara. Berikut profil singkat kedua komunitas tersebut :

Indonesia Setara

Indonesia Setara adalah sebuah Organisasi Non Profit yang dibentuk pada November 2010 yang memiliki tujuan untuk membangun mindset percaya diri bahwa rakyat Indonesia mampu berprestasi untuk mendorong kemajuan bangsa. Indonesia Setara Foundation akan membantu pelaku UMKM dan Koperasi agar mampu mengakses peluang dan kesempatan tersebut sehingga tumbuh dan berkembang. Fokus utama Indonesia Setara adalah mengembangkan kapasitas dan jejaring. Indonesia Setara akan membuka akses pendidikan, akses terhadap permodalan, dan akses terhadap sumber daya maupun jejaring.

Melalui gerakan yang digagas Sandiaga Uno ini, masyarakat diharapkan mempunyai semangat juang untuk mengubah kehidupan, mulai dari diri sendiri, keluarga, komunitas, dan wilayah. Gerakan Indonesia Setara berfokus pada pemberdayaan UMKM, yang merupakan kunci utama supaya potensi 'survive' negeri ini menjadi lebih tinggi. Indonesia Setara juga secara aktif mendatangi kampus-kampus dan organisasi sebagai 'engagement' langsung untuk mengajak masyarakat melakukan perubahan menuju kesetaraan.

\section{Asosiasi Social entrepreneurship Indonesia (AKSI)}

AKSI merupakan sebuah wadah atau organisasi untuk menjaring para kewriausahaan sosial di seluruh indonesia yang memiliki visi untuk menciptakan lingkungan yang mendukung (enabling environment) untuk tumbuhnya social entrepreneurship di Indonesia. Sedangkan misi dari AKSI adalah untuk :

1. Menciptakan lingkungan yang mendukung (enabling environment) untuk tumbuhnya social entrepreneurship di Indonesia.

2.Mendorong social entrepreneurship yang berkelanjutan melalui layanan peningkatan kapasitas.

3. Membangun jaringan dengan berbagai pihak, di sektor social entrepreneurship maupun lintas sektor, di tingkat nasional, regional dan internasional untuk memperkuat komitmen dan upaya di sektor sosial.

AKSI merupakan sebuah wadah berkumpulnya para penggiat social entrepreneurship yang bertujuan untuk membangun keberdayaan masyarakat secara berkelanjutan melalui inovasi di bidang sosial. AKSI lahir atas keprihatinan terhadap situasi bangsa Indonesia yang dilanda banyak permasalahan sosial, seperti kemiskinan, kerusakan lingkungan, dsb. Beberapa program yang dimiliki AKSI, antara lain memperkuat keanggotaan, memperkuat gerakan kewirausahaan di Indonesia, dan memperkuat kelembagaan asosiasi. AKSI juga aktif melakukan pembinaan social entrepreneurship dan ekspedisi ke daerah terpencil untuk membantu memecahkan permasalahan sosial di sana.

\section{Pelaku social entrepreneurship di Indonesia}

Cabang social entrepreneurship berinduk pada bidang yang lebih luas, yaitu kewirausahaan. Kewirausahaan dikembangkan dengan menggunakan data empiris dari dunia bisnis. Sejumlah upaya pengembangan wirausaha bisnis dapat menjadi acuan untuk pengembangan social entrepreneurship. Untuk menekuni dunia social entrepreneurship, membutuhkan komitmen tinggi dan rela berkorban dalam segala hal, mulai dari finansial (uang), waktu, serta pantang menyerah. Dan Indonesia beruntung memiliki cukup banyak pelaku social entrepreneurship yang dapat mendukung tumbuhnya semangat social entrepreneurship pada sekelompok masyarakat. Berikut adalah sedikit contoh dari beberapa individu yang berkecimpung dalam social entrepreneurship di Indonesia dan telah memperoleh penghargaan:

\section{Aris Hartana dan Pembudidayaan Ikan Koi di Dusun Dangkel Wetan - Magelang}

Dusun Dangkel Wetan berjarang sekitar 25 kilometer dari Kabupaten Magelang - Jawa Tengah. Suasana dusun yang asri, dengan hamparan sawah di kiri dan kanan jalan, memberi impresi yang segar. Rumah-rumah warga berjarak di dusun yang masuk bagian dari Desa Karangtalun, Ngluwar, Kabupaten Magelang ini. Meski harus masuk ke jalan-jalan kecil di dusun, tidak sulit mencari kediaman Aris 
Hartana. Orang disekitarnya menyebutnya “Aris Koi”, dimana nama ini diambil dari kegiatan Aris yang membudidayakan ikan asal Jepang ini.

Keseriusannya dalam dunia Koi dengan mudah dilihat dari rumahnya. Disebelah rumahnya berjajar tujuh kolam budidaya Koi. Dikolam itu ada beragam jenis induk Koi yang berjumlah sekitar 100 ekor, juga ribuan benih di kolam. Di belakang rumahnya masih ada sepuluh kolam yang sedikit lebih kecil untuk menampung hasil panen Koi para peternak. Tidak jauh dari rumahnya, disebuah petak sawah, Ikan Koi beragam ukuran dengan mudah ditemui. Kolam itu milik tetangganya yang diajak bekerja sama. Sarjo, tetangga Aris yang diajak bekerja sama "mengelola lahan" mengatakan, dalam sebulan dari satu kolam, dia bisa mendapatkan Rp. 500.000, hingga Rp 1,5 juta.

Perkenalan pertama Aris dengan Ikan Koi terjadi pada tahun 1995. Saat itu, Aris mempunyai kenalan yang memelihara Ikan Koi. Dia kagum dengan ikan yang bercorak indah ini. Dia pun mulai mempelajari segala hal tentang Ikan Koi. Jenis, ukuran, corak, warna, termasuk cara memelihara Ikan Koi. Bermodal Rp.50.000, dia membeli bibit Ikan Koi. Memasuki awal 2000-an, dia mulai mengajak warga untuk beternak. Ada 20 orang didesanya yang tertarik bergabung dan mulai mempraktikkan beternak Ikan Koi. Perlahan tapi pasti usahanya beternak Ikan Koi memberikan hasil. Kini Aris Hartana dan para peternak Ikon Koi didesannya menikmati hasil jerih payahnya selama ini. Dalam sebulan masing-masing peternak Ikan Koi dapat meraup pendapatan belasan juta rupiah.

Semangat, kerja keras, inovasi dan kreatifitas serta semangat kewirausahaan merupakan kunci keberhasilan Aris dan rekan-rekannya dalam membudidayakan Ikan Koi di Magelang. Dan atas keuletannya tersebut Aris Hartana mendapatkan penghargaan sebagai Pemenang Citi Microentrepreneurship Awards 2016-2017 Kategory Fishery.

\section{Siyam Sumartini : Mengelola Sampah Kekinian}

Bertahun-tahun tinggal berdampingan dengan tempat pembuangan akhir sampah Kota Madiun membuat perempuan 50 tahun itu jengah. Tumpukan sampah menyebabkan bau busuk yang menusuk hidung, serbuan lalat, dan lingkungan menjadi kumuh. Lingkungan yang "sakit" itu pun menyebabkan warga penghuninya rentan terserang beragam penyakit, seperti diare dan gatal-gatal. Klimaksnya terjadi saat kampungnya menjadi daerah endemis demam berdarah. Banyak warga terserang dan nyawa mereka pun terenggut. Saat itulah Siyam merasa situasi seperti ini tidak boleh dibiarkan.

Sumber masalahnya sampah. Ironisnya, semakin sampah dijauhi, semakin besar masalah yang ditimbulkan. Siyam pun akhirnya berpikir bagaimana caranya menyelami sampah agar berubah menjadi sesuatu yang bermanfaat atau membawa berkah. Awalnya dia berkreasi dengan sampah. Beragam barang bekas dikumpulkan dan dijadikan bahan aneka produk kerajinan. Bunga cantik yang terbuat dari sendok plastik bekas, tas unik atau goody bag berbahan plastik keresek, dan beberapa barang yang lain. Beragam kreasi daur ulang itu dia pamerkan disejumlah acar dan dijual. Harganya pun tidak murah. Sebagai gambaran, sebuah keranjang air minum kemasan dari gelas plastik dan koran bekas laku dijual Rp. 250.000,-. Adapun goody bag unik dijual Rp. 5.000,-.

Siyam menularkan kesuksesan kreasi daur ulangnya kepada tetangganya. Dia menunjukkan barang bekas yang awalnya tidak bernilai bisa diubah menjadi produk kerajinan bernilai jual tinggi. Hasil penjualan itu bisa digunakan untuk membantu perekonomian keluarga. Siyam juga mengajak warga dilingkungannya mengelola sampah rumah tangga dengan mendirikan Bank Sampah Matahari pada tahun 2010. Tujuannya mereduksi sampah rumah tangga dengan cara memilih dan memilah sampah yang bernilai ekonomi atau bisa daur ulang. Dengan adanya proses pemilahan dan pemilihan, sampah yang dibuang ke TPA berkurang. Disisi lain, sampah yang dipilah bisa dijual langsung dan menghasilkan uang. Apabila menginginkan nilai tambah, maka sampah harus dikreasi menjadi produk daur ulang.

Kini, Bank Sampah Matahari yang dirintisnya telah direplikasi di 27 kelurahan di Kota Madiun. Setiap kelurahan ada satu hingga dua bank sampah sehingga total terdapat 50 bank sampah di "kota pecel" itu. Kesuksesannya mengelola Bank Sampah Matahari semakin diakui setelah terpilih dalam TOP 99 Inovasi Pelayanan Publik 2016.

Hal yang menarik untuk dicermati dari kedua profil di atas adalah adanya kesamaan dalam hal: mereka berjiwa wirausaha, kreatif dan inovatif, serta memiliki kepedulian sosial yang tinggi. Bangsa ini membutuhkan banyak sosok seperti mereka, yang bisa memadukan antara aktivitas bisnis dan sosial. Perjalanan para pengusaha sosial ini tentunya masih panjang untuk membuktikan diri sebagai social entrepreneurship yang sejati, namun inisiatif mereka perlu diberikan apresiasi secara khusus, karena mereka tidak sekadar mengembangkan bisnis tapi juga memecahkan persoalan sosial. 
Telaah secara lebih rinci terhadap profil pelaku social entrepreneurship diatas berdasarkan kajian elemen social entrepreneurship dijelaskan dalam tabel berikut :

Tabel: Profil social entrepreneurship dan elemen social entrepreneurship

\begin{tabular}{|c|c|c|}
\hline Elemen social entrepreneurship & $\begin{array}{l}\text { Aris Hartana dan Pembudidayaan } \\
\text { Ikan Koi di Magelang }\end{array}$ & $\begin{array}{l}\text { Siyam Sumartini : Mengelola } \\
\text { Sampah Kekinian Di Madiun }\end{array}$ \\
\hline Social Value & 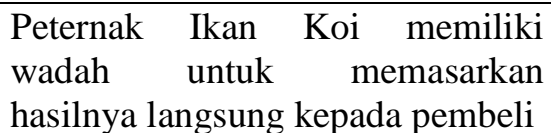 & $\begin{array}{ll}\text { Mereduksi sampah, } & \text { dengan } \\
\text { memilah dan memilih } & \text { sampah } \\
\text { yang bisa didaur ulang. } & \end{array}$ \\
\hline Civil Society & $\begin{array}{l}\text { Masyarakat di Dusun Dangkel } \\
\text { Wetan-Magelang }\end{array}$ & Masyarakat di Kota Madiun \\
\hline Innovation & $\begin{array}{l}\text { Beternak } \text { Ikan Koi dilahan yang } \\
\text { selama ini relatif kurang } \\
\text { dioptimalkan }\end{array}$ & $\begin{array}{l}\text { Mendaur ulang sampah, sehingga } \\
\text { memiliki nilai keekonomisan yang } \\
\text { tinggi }\end{array}$ \\
\hline Economic Activity & $\begin{array}{l}\text { Membudidayakan Ikan Koi } \\
\text { kemudian dijual hingga mencapai } \\
\text { usia keekonomisan. }\end{array}$ & $\begin{array}{l}\text { Daur ulang sampah, menghasilkan } \\
\text { keranjang air minum dan goody } \\
\text { bag, serta barang-barang lain. }\end{array}$ \\
\hline
\end{tabular}

Sumber: Data yang diolah oleh penulis.

\section{Peranan Social entrepreneurship dalam Pembangunan Ekonomi}

Peran social entrepreneur dapat berperan baik dari segi internal maupun eksternal. Peran social entrepreneur dari segi internal adalah mengurai tingkat ketergantungan terhadap orang lain, menciptakan rasa kepercayaan diri, dan dapat meningkatkan daya tarik pelakunya. Dari segi eksternal, kewirausahaan dapat berperan sebagai menyediakan lapangan pekerjaan bagi masyarakat yang belum mendapatkan peluang kerja. Dengan cara itulah kewirausahaan dapat juga membantu mengurai atau memberantas tingkat pengangguran yang selama ini jadi beban pikiran masyarakat dan permasalahan sosial lainnya.

Social entrepreneurship juga berperan dalam pembangunan ekonomi karena ternyata mampu memberikan daya cipta nilai-nilai sosial maupun ekonomi, seperti yang dipaparkan oleh Santosa (2007) berikut:

a. Menciptakan kesempatan kerja

Manfaat ekonomi yang dirasakan dari Social entrepreneurship di berbagai negara adalah penciptaan kesempatan kerja baru yang meningkat secara signifikan.

b. Melakukan inovasi dan kreasi baru terhadap produksi barang ataupun jasa yang dibutuhkan masyarakat. Inovasi dan kreasi baru terhadap jasa kemasyarakatan yang selama ini tidak tertangani oleh pemerintah dapat dilakukan oleh kelompok social entrepereneur seperti misalnya : pembentukan bank sampah, pengadaan perpustakaan keliling bagi daerah terpencil, edukasi bagi masyarakat untuk mengoptimalkan lahan sempit agar ditanami tanaman produktif, dll. Seringkali standar pelayanan yang dilakukan pemerintah tidak mengena sasaran karena terlalu kaku mengikuti standar yang ditetapkan. Di lain sisi, social entrepreneurs mampu untuk mengatasinya karena memang dilakukan dengan penuh dedikasi dan berangkat dari sebuah misi sosial.

c. Menjadi modal sosial

Modal sosial yang terdiri dari saling pengertian (shared value), kepercayaan (trust) dan budaya kerjasama (a culture of cooperation) merupakan bentuk yang paling penting dari modal yang dapat diciptakan oleh social entrepreneur (Leadbeater dalam Santosa, 2007). Siklus modal sosial diawali dengan penyertaan awal dari modal sosial oleh pengusaha sosial. Selanjutnya dibangun jaringan kepercayaan dan kerjasama yang makin meningkat sehingga dapat akses kepada pembangunan fisik, aspek keuangan dan sumber daya manusia. Pada saat unit usaha dibentuk (organizational capital) dan saat usaha sosial mulai menguntungkan maka makin banyak sarana sosial dibangun.

d. Peningkatan Kesetaraan

Salah satu tujuan pembangunan ekonomi adalah terwujudnya kesetaraan dan pemerataan kesejahteraan masyarakat. Melalui social entrepreneurship, tujuan tersebut akan dapat diwujudkan karena para pelaku bisnis yang semula hanya memikirkan pencapaian keuntungan yang maksimal, selanjutnya akan tergerak pula untuk memikirkan pemerataan pendapatan agar dapat dilakukan pembangunan ekonomi yang berkelanjutan. Contoh keberhasilan Grameen Bank adalah salah satu bukti dari manfaat ini. 


\section{Tantangan Social Entrepreneur di Era Persaingan Bebas}

Namun demikian bukan berarti para pelaku social entrepreneur dapat mengimplementasikan gagasannya secara mudah. Seperti telah dijelaskan diatas, bahwa kendala yang dihadapi oleh Social Entrepreuners di era persaingan bebas semakin rumit dan kompleks. Berbagai tantangan yang dihadapi oleh Social Entrepreuners antara lain adalah masalah pendanaan, pendidikan untuk para pemimpin dimasa mendatang yang menyadari tentang pentingnya social entrepreneurship, dan kurangnya insentif yang diberikan oleh pemerintah untuk meringankan beban lembaga-lembaga atau bahkan individu yang bergerak dibidang sosial. Oleh karena itu, di era globalisasi seperti saat ini, Social Entrepreneurs harus didukung oleh Social Investor agar inovasinya, ide-ide, dan terobosan barunya dapat diwujudkan. Tetapi haruslah disadari bahwa Social Entrepreneurship bukanlah satu-satunya obat untuk mengatasi permasalahan sosial yang dihadapi, karena dalam kenyataannya, hal tersebut juga sangat dipengaruhi oleh kerangka dan struktur perekonomian yang ada di suatu negara. Namun demikian, walaupun tantangan yang dihadapi semakin tinggi, seharusnya tetap harus muncul keberanian untuk mulai membentuk change makers, sehingga setiap setiap individu harus diupayakan untuk dapat menjadi agen perubahan di lingkunganya. Lebih lanjut Austin dkk (dalam Nicholls. 2006) mengemukakan sejumlah tantangan yang dihadapi oleh social entrepreneurship, yaitu:

Kepemimpinan; dengan tiga dimensi penting yaitu :

- Visi, Social Entrepreuners harus memiliki visi dimana dimensi sosial merupakan pusat dan bagian integral dari kehidupan perusahaan

- Legitimasi, Social Entrepreuners harus menciptakan lingkungan internal yang tepat dan sesuai dengan harapan yang ingin diwujudkannya

- Pemberdayaan, Social Entrepreuners harus memberi peluang agen perubahan lainnya agar mampu membangun dan memutuskan suatu proses perubahan menuju kea rah yang lebih baik .

Strategi; dengan tiga elemen yaitu:

- Alignment, dimensi sosial dan dimensi bisnis dalam strategi yang dijalankan harus selaras satu sama lainnya.

- Leveraging core competencies, fokus pada menemukan upaya kreatif dalam memobilisasi dan menyebarluaskan aset kunci serta komponen keberhasilan usaha, sehingga akan tercipta hubungan nilai sosial dan usaha yang berlipat ganda untuk terciptanya nilai ekonomi dan sosial yang lebih besar lagi.

- Partnering, bermitra dan menciptakan aliansi dengan pihak lainnya, untuk mendukung dan memperkuat proses social entrepreuners.

Heidjrachman dalam Buchari Alma (2006) mengidentifikasi 4 tantangan yang menjadi kelemahan social entrepreuners;

- Sifat mental yang cenderung meremehkan mutu

- Sifat mental yang suka menerabas (tidak mengikuti suatu proses yang baik)

- Tidak percaya pada diri sendiri, serta

- Kurang disiplin diri untuk mewujudkan perubahan ke arah yang lebih baik

Sementara itu Zimmerer dalam Suryana (2003) mengemukakan beberapa faktor yang membuat entrepreuners gagal dalam menjalankan aktivitasnya:

a. Tidak kompeten dalam manajerial. Tidak kompeten atau tidak memiliki kemampuan dan pengetahuan mengelola suatu usaha merupakan faktor utama yang membuat social entrepreuners tidak berhasil ketika memulai suatu usaha

b. Kurang berpengalaman, baik dalam kemampuan teknik, kemampuan memvisualisasikan usaha, kemampuan mengkoordinasikan, ketermapilan mengelola sumberdaya manusia, maupun kemampuan mengintegrasikan suatu kegiatan.

c. Gagal dalam perencanaan. Perencanaan merupakan titik awal social entrepreuners dalam memulai suatu kegiatan. Sekali gagal dalam perencanaan maka akan mengalami kesulitan dalam menjalankan pelaksanaan.

d. Sikap yang kurang sungguh-sungguh dalam berusaha. Sikap yang setengah-setengah terhadap usaha akan mengakibatkan usaha yang dilakukan oleh social entrepreuners menjadi labil dan gagal. Dengan sikap setengah hati, kemungkinan gagal menjadi besar.

e. Ketidakmampuan dalam melakukan peralihan/transisi. Social entrepreuners yang tidak siap menghadapi dan melakukan perubahan, tidak akan menjadi social entrepreuners yang berhasil. Keberhasilan dalam berwirausaha hanya bisa diperoleh apabila berani mengadakan perubahan dan mampu membuat peralihan setiap waktu. 


\section{KESIMPULAN}

Era globalisasi merupakan suatu keniscayaan, yang mau tidak mau, suka tidak suka harus dihadapi. Persaingan bebas mempunyai dua sisi yang tidak dapat dipisahkan. Disatu sisi ketika suatu bangsa "siap" serta memiliki kualitas yang unggul, maka bangsa tersebut akan dapat memetik manfaat yang besar dari globalisasi yang terjadi. Di sisi lain, ketika kualitas diberbagai bidang yang dimiliki oleh suatu bangsa masih rendah, maka globalisasi justru akan menjadi sesuatu yang menakutkan, karena akan menggilas semua sendisendi usaha yang ada di negara tersebut. Salah satu yang bisa dilakukan oleh suatu negara dalam mengahadapi era persaingan bebas ini, adalah dengan menumbuhkembangkan serta memperbanyak social entrepreuners. Social Entrepreuners adalah sebuah model bisnis baru yang bermanfaat bagi pemberdayaan masyarakat sekitar. Hasil akhir yang ingin diraih social entrepreuners, tidak melulu keuntungan materi semata, lebih dari itu adalah bagaimana gagasan yang diajukan dapat memberikan dampak yang baik bagi masyarakat secara luas.

Social entrepreneurship merupakan salah satu bentuk kewirausahaan yang bertujuan untuk membantu masyarakat. Bisnis sosial bisa jadi salah satu bentuk social entrepreneurship tetapi tidak semua social entrepreneurship berbentuk bisnis sosial. Social entrepreneurship adalah inisiatif (ekonomi atau non ekonomi, bertujuan profit atau non profit) yang inovatif. Social entrepreneurship melihat masalah sebagai peluang untuk membentuk sebuah model bisnis baru yang bermanfaat bagi pemberdayaan masyarakat sekitar.

Namun demikian, tantangan ataupun kendala yang dihadapi oleh social entrepreuners sangatlah kompleks. Tantangan yang dihadapi bukan hanya bersifat internal, melainkan juga tantangan yang berasal dari lingkungan global.

Social entrepreneurship menjadi suatu fenomena unik dan menarik, karena mempunyai banyak perbedaan dengan wirausaha tradisional. Apabila wirausaha tradisional lebih berfokus dengan keuntungan materi dan hanya kepuasan pelanggan semata, sebaliknya social entrepreneurship melibatkan berbagai ilmu pengetahuan dalam pengembangan dan dalam praktiknya dilapangan.

Untuk mewujudkan bisnis sosial yang berkelanjutan memang membutuhkan jaringan dan kerjasama dengan berbagai pihak. Keberlangsungan hidup dari social entrepreneurship hendaknya menjadi perhatian bagi berbagai kalangan, yaitu pemerintah, masyarakat, perusahaan, ataupun lembaga pendidikan seperti universitas, sebab peranan social entrepreneurship di suatu negara sangat besar bagi perekonomian negara tersebut, karena dapat menyerap banyak tenaga kerja, terutama tenaga kerja yang berkualitas yang tidak mendapatkan peluang di sektor formal.

\section{Daftar Pustaka}

Badan Pusat Statistik, 2015, Laporan Bulanan Data Sosial Ekonomi Agustus 2015, BPS.

Bunyamin Maftuh, 2016. Peran OJK Dalam Meningkatkan Ketahanan UMKM Indonesia dalam Menyongsong MEA. Seminar Nasional di Universitas Negeri Jakarta.

Alma Buchari, 2006, Kewirausahaan. Alfabeta. Bandung.

Cukier, Wendy, Susan Trenholm, dan Dale Carl, 2011, "Social Entrepreneurship : A Content Analysis", Journal of Strategic Innovation and Sustainability.

Firdaus Djaelani, 2016. Peran OJK Dalam Meningkatkan Ketahanan UMKM Indonesia dalam Menyongsong MEA. Seminar Nasional di Universitas Negeri Jakarta.

Hulgard. Lars, 2010, Discourses of Social Entrepreneurship-Variation of The Same Theme? EMES European Research Network.

Mort, Gillian Sullivan \& Jay Weerawardena, 2003, Social entrepreneurship: towards conceptualisation, International Journal of Nonprofit and Voluntary Sector Marketing.

Moulaert, F., MacCallum, D., Mehmood, A., \& Hamdouch, A. ,2013, The international handbook on social innovation. Collective action, social learning and transdisciplinary research. Cheltenham: Edgar Elgar 
Palesangi, Muliadi, 2012, "Pemuda Indonesia dan Kewirausahaan Sosial", Prosiding Seminar Nasional Competitive Advantage, Universitas Pesantren Tinggi Darul „Ulum.

Saiman, Marwoto, 2011, “Inovasi Metode Pembelajaran Sejarah”, Jurnal Ilmu-Ilmu Sejarah, Budaya dan Sosial.

Santosa, Setyanto P., 2007, "Peran Social Entrepreneurship dalam Pembangunan”, Makalah dipresentasikan di acara Seminar "Membangun Sinergisitas Bangsa Menuju Indonesia Yang Inovatif, Inventif dan Kompetitif', Universitas Brawijaya.

Sledzik, Karol, 2013, "Schumpeter"s View on Innovation and Entrepreneurship", Journal of Social Scence Research Network.

Suharti, Lilelu dan Hani Sirine, 2011, "Faktor-Faktor yang Berpengaruh Terhadap Niat Kewirausahaan (Entrepreneurial Intention)", Jurnal Manajemen dan Kewirausahaan.

Suryana, 2003, Kewirausahaan”, Penerbit Salemba Empat. Jakarta

United Nations Development Programme , 2015, The 2015 Human Development Report „Work for Human Development, UNDP

Utomo, Hardi, 2014, "Menumbuhkan Minat Kewairausahaan Sosial”, Jurnal Ilmiah Among Makarti.

Widiastusy, Ratna dan Meily Margaretha, 2011, "Socio Entrepreneurship : Tinjauan Teori dan Perannya Bagi Masyarakat", Jurnal Manajemen Universitas Kristen Maranatha.

http://www.ashoka.or.id

http://www.aksi-indonesia.org/

http://indonesiasetara.org/

http://www.asean.org 